\title{
Gene Cloning and Tissue Expression Analysis of a PR-5 Thaumatin-Like Protein in Phellinus weirii-Infected Douglas-Fir
}

\author{
Arezoo Zamani, Rona N. Sturrock, \\ Abul K. M. Ekramoddoullah, Jun Jun Liu, and Xueshu Yu
}

Natural Resources Canada, Canadian Forest Service, Pacific Forestry Centre, 506 West Burnside Road, Victoria, British Columbia, V8Z 1M5, Canada.

Accepted for publication 25 June 2004.

\begin{abstract}
Zamani, A., Sturrock, R. N., Ekramoddoullah, A. K. M., Liu, J. J., and Yu, X. 2004. Gene cloning and tissue expression analysis of a PR-5 thaumatin-like protein in Phellinus weirii-infected Douglas-fir. Phytopathology 94:1235-1243.

In western North America, Douglas-fir (Pseudotsuga menziesii) is the most economically important conifer species susceptible to laminated root rot caused by Phellinus weirii. While attempting to internally sequence an endochitinase found to be up-regulated in $P$. weirii-infected Douglas-fir roots, we obtained overlapping peptide fragments showing $28 \%$ similarity with a PR-5 thaumatin-like protein (TLP) designated PmTLP (Pm for Pseudotsuga menziesii). A rabbit polyclonal antibody was reared against a synthetic peptide composed of a 29-amino-acid-long, conserved, internal sequence of PmTLP and purified by immunoaffinity. Western immunoblot analysis of infected roots of 24-year-old coastal

PmTLP in roots of 25-year-old interior Douglas-firs naturally infected with a related pathogen, Armillaria ostoyae, and results showed significantly higher levels of PmTLP in bark tissues adjacent to infection $(P<$ 0.05 ) than in uninfected tissue. Using polymerase chain reaction (PCR)based cloning, the cDNA of PmTLP was shown to have a 702-bp open reading frame with a signal peptide cleavage site at $155 \mathrm{bp}$ corresponding to a 29-amino-acid-long residue prior to the start of the N-terminal. Based on the deduced amino acid sequence, the molecular mass of the putative PmTLP was calculated to be $21.0 \mathrm{kDa}$ with an isoelectric point of 3.71 . Alignment analysis of PmTLP cDNA with a representative genomic DNA PCR sequence showed presence of one intron of variable size, within the coding region. The induction of PmTLP at the site of root infection and its presence in needle tissue suggests a general role for this protein in adaptation to stress and may be part of an integrated defense response initiated by the host to impede further pathogen spread.
\end{abstract} Douglas-fir showed significantly higher amounts of PmTLP $(P<0.01)$ closest to the point of $P$. weirii inoculation and infection than in uninfected regions of the same root. The antibody was also used to screen for
Additional keywords: ectotrophic mycelium, defense-related protein, mass spectrometry analysis.
The significant reduction in second-growth Douglas-fir (Pseudotsuga menziesii [Mirb.] Franco) stand density and timber volume losses due to Phellinus weirii (Murrill) R.L. Gilbertson root infection have adversely affected commercial yields of this important tree crop in western North America. P. weirii is a pathogenic root-inhabiting fungus that spreads by root contact. Infected roots and stumps can serve as a viable inoculum source for many years. Initially, $P$. weirii grows along host roots as ectotrophic or root-surface mycelium. The ectotrophic mycelium eventually penetrates intact or injured bark through to cambial and wood tissues, where it causes decay (30). Ectotrophic mycelium often advances considerably beyond the limits of internal decay. Armillaria ostoyae is another aggressive root pathogen affecting the productivity of Douglas-fir. Like $P$. weirii, A. ostoyae can also spread by root contact, and it infects healthy tissue by extension of white mycelial fans into bark and cambial tissues (19). Initial infection of Douglas-fir root tissue by pathogenic fungi results in the formation of necrophylactic periderms (20). Infected roots often form lesions and callus tissue $(18,19,33)$. There is also evidence that traumatic resin ducts are formed in Douglas-fir roots in response to infection by both $P$. weirii and A. ostoyae (R. N.

Corresponding author: A. Ekramoddoullah

E-mail address: aekramod@pfc.cfs.nrcan.gc.ca

Publication no. P-2004-0922-01R

(C) 2004, Her Majesty the Queen in right of Canada, Natural Resources Canada, Canadian Forest Service
Sturrock and M. Cruickshank, unpublished data). However, little is known about the biochemical mechanisms underlying these proposed defense responses by Douglas-fir. By looking at two related phytopathogenic fungi and their impact on host protein synthesis in infected Douglas-fir tissues, a better understanding of the disease process can be gained.

Host-encoded, defense-related enzymes such as peroxidase, polyphenol oxidase, and phenylalanine ammonia-lyase involved in the biosynthesis of lignin, phenolics, and phytoalexins have been shown to enhance the mechanical strength of host cell walls and act as antimicrobial agents to restrict pathogen development $(5,23,32)$. The accumulation of pathogenesis-related (PR) proteins, both locally and systemically, is an integral part of this defense response initiated by host plants under biotic and abiotic stress to impede further pathogen ingress $(31,32)$. Systemic acquired resistance provides general defense to the host against further nonspecific infection (16). Localized PR protein induction is related to the hypersensitive response, whereby cells in immediate contact with the pathogen rapidly necrose to keep the pathogen restricted to the site of infection (32). It is the collective, coordinated expression of multiple defense-related enzymes and PR proteins that effectively inhibit pathogen spread.

Based on structural and functional properties, up to 17 families of PR proteins have been identified thus far in mono- and dicotyledonous plants, with functions ranging from cell wall rigidification to signal transduction and antimicrobial activity (5). In conifer pathosystems, however, very few PR proteins and their genes have been isolated and characterized. 
The PR-5 family of proteins includes permatins, osmotins, zeamatins, and thaumatin-like proteins (TLP) that show amino acid homology with the intensely sweet-tasting protein thaumatin derived from fruits of Thaumatococcus daniellii Benth (6). They are generally of low molecular weight (under $35 \mathrm{kDa}$ ) and can be found sequestered in vacuoles or in intercellular washing fluids. PR-5 proteins have shown antifungal activity in vitro and although the precise mechanism of action is not clear, it is believed to involve an increase in fungal membrane permeability $(1,25)$. It has been suggested that formation of a transmembrane pore by PR-5 protein interaction with the fungal plasma membranes causes an influx of water resulting in osmotic rupture (25). X-ray crystallography studies performed on zeamatin from maize and osmotin from tobacco have shown that an acidic surface cleft may be the binding site for a receptor on fungal plasma membranes $(3,14)$. The cleft is known to be conserved among other antifungal PR proteins (15). Other studies show TLPs to function as antifreeze proteins in cold acclimated winter rye by inhibiting intercellular ice growth and recrystallization (34), and show sequence similarity to a number of plant-derived allergens $(12,17)$.

In this paper, we report the isolation and molecular characterization of one such putative PR protein, a TLP from $P$. weiriiinfected Douglas-fir roots (PmTLP). The objectives of this work were to determine if there is a correlation of PmTLP expression in Douglas-fir with root infection sites of $P$. weirii and $A$. ostoyae mycelium.

\section{MATERIALS AND METHODS}

Plant material and sampling. P. weirii-infected juvenile Douglas-fir. Ten-year-old Douglas-fir trees growing at a field site at the Pacific Forestry Centre in Victoria, British Columbia, Canada were inoculated with $P$. weirii using inoculum units (29) placed in direct contact with roots. Root and needle tissues were sampled for genomic DNA and RNA analysis from a tree showing stunted crown development, significant root surface $P$. weirii mycelium, and taproot decay symptomatic of incipient $P$. weirii infection.

Root tissue from P. weirii-infected mature Douglas-fir. Twelve 24-year-old coastal Douglas-fir trees growing at the northeast end of Cowichan Lake, British Columbia in the Coastal Western Hemlock biogeoclimatic zone were inoculated with $P$. weirii isolate PFC-Pw581 using inoculation units as described previously (29). After a year of contact with an inoculum unit, the inoculated root from each tree was excavated. Pins were pressed into the bark to mark where inoculum units were placed, and at the most distal and proximal margins of ectotrophic or surface mycelial (ETM) spread. In the laboratory, roots were washed and bark tissues were sampled at six locations. At the distal margin of ETM, root bark was sampled (i) within the ETM zone, approximately $2 \mathrm{~cm}$ inside the distal infection margin (Dist-INF), (ii) $2 \mathrm{~cm}$ beyond or adjacent to the distal infection margin (Dist-ADJ), and (iii) 5 to $10 \mathrm{~cm}$ beyond the distal infection margin in an uninfected region of the root (Dist-UNINF). Similar sampling was done in the proximal region of ETM with the following labels: (i) Prox-INF, (ii) ProxADJ, and (iii) Prox-UNINF. At each sampling site, bark sections ( 1 by $3 \mathrm{~cm}$ ) including tissues of the vascular cambium were removed, wrapped in aluminum foil, labeled, immediately frozen, and freeze-dried. The cambial tissues were separated from the outer bark tissues and then cut into small pieces and ground to a fine powder under liquid nitrogen. Ground powder was stored at $-20^{\circ} \mathrm{C}$ and later used for protein extraction.

Root tissue from A. ostoyae-infected mature Douglas-fir. Five 25-year-old Douglas-fir trees naturally infected with A. ostoyae were identified in the Interior Cedar-Hemlock biogeoclimatic zone of the Kamloops Forest District of British Columbia. Each tree was sampled seasonally in the spring (May), summer (July), and autumn (September). At each sampling time, a healthy and an infected root were selected from each tree and a bark section ( 1 by $1 \mathrm{~cm}$ ) including the vascular cambium was removed. From an infected root, bark tissue was sampled next to the infection front, which was recognized by host tissue browning. All samples were packaged and processed as described previously (B) for $P$. weirii-infected roots.

Protein extraction and separation. Total root bark proteins from $P$. weirii- and A. ostoyae-infected Douglas-fir were extracted, and concentrations of all samples were determined following a standard protocol (7). To determine if specific proteins were present in other parts of the tree, needles from $P$. weiriiinfected juvenile Douglas-fir were sampled and the apoplastic fluid was collected immediately by vacuum infiltration (35). Protein extracts were separated on an equal protein basis using sodium dodecyl sulfate-polyacrylamide gel electrophoresis (SDSPAGE) as previously described (26). Proteins were separated at a constant current of $25 \mathrm{~mA}$ per stacking gel and $35 \mathrm{~mA}$ per separating gel. A Coomassie brilliant blue R-250 (CBB; Sigma Chemical, St. Louis) triple stain procedure was used to stain gels for sequencing purposes. The triple stain procedure involved an initial overnight incubation in Coomassie stain solution $(0.05 \%$ $\mathrm{CBB}, 25 \%$ isopropanol, and $10 \%$ acetic acid) at room temperature on a shaker. Gels were transferred to a less concentrated stain $(0.005 \% \mathrm{CBB}, 10 \%$ isopropanol, and $10 \%$ acetic acid) for $6 \mathrm{~h}$ followed by a more dilute, overnight incubation with only $0.0025 \%$ CBB (10\% isopropanol and $10 \%$ acetic acid). Gels were destained for $2 \mathrm{~h}$ in $10 \%$ acetic acid for complete background removal.

Amino acid sequencing and production of rabbit anti$P m$ TLP antibody. Due to the abundance of the $24-\mathrm{kDa}$ polypeptide in the apoplastic fluid of needles collected from $P$. weiriiinfected Douglas-fir, this was the sample source used for amino acid sequencing. The protein of interest was cut directly from the $\mathrm{CBB}$ gel and sent for internal amino acid sequencing at the Beckman Research Institute of the City of Hope, Duarte, CA. The polypeptide was tryptically digested and analyzed using matrixassisted laser desorption/ionization (MALDI) to give a tandem mass spectrum.

$\mathrm{N}$-terminal sequence analysis of the 24-kDa polypeptide was carried out at the Department of Biochemistry and Microbiology, University of Victoria, British Columbia, Canada as previously described (9). A peptide was synthesized against an immunogenic 29-amino-acid-long sequence of PmTLP and used in the production of a rabbit anti-thaumatin-like polyclonal antibody (termed PmTLP-pab) carried out by Multiple Peptide Systems (San Diego, CA). SDS-PAGE and western blots were performed to determine antibody purity and specificity.

Western blot analysis and Pm TLP quantification. Total protein extracts of infected and uninfected root tissues were separated with SDS-PAGE, electrophoretically transferred to polyvinylidene fluoride membrane (PVDF; Millipore Corp., Bedford, MA), and probed with PmTLP-pab following a standard protocol (9). As determined by preliminary immunoblots, one of the samples containing a sufficient amount of PmTLP was used as an internal control and applied to all gels. PmTLP levels on all immunoblots were estimated based on this internal control. Membranes were scanned using a computer interfaced GS-800 Imaging Densitometer (Bio-Rad Laboratories, Mississauga, Canada). BioRad's Quantity One software (version 4.4) was used for the quantification of protein bands. The optical density of all the pixels within the band boundary was measured based on internal calibration standards specific to the scanner and values were reported in OD $\times \mathrm{mm}$ (optical density multiplied by band width in millimeters).

Two-Dimensional gel electrophoresis. To determine the number of PmTLP isoforms, analytical two-dimensional (2-D) electrophoresis was carried out with the Millipore Investigator 2-D gel electrophoresis system (Millipore Corp.) following the protocol outlined in Ekramoddoullah and Tan (8). Following 2-D 
electrophoresis, gels were either silver stained (22) or subjected to western immunoblot analysis using PmTLP-pab as probe.

Total RNA extraction and cDNA synthesis. A composite RNA extract was prepared according to Schultz et al. (27) from the roots and needles $(1 \mathrm{~g}$ of lyophilized tissue) of a 10-year-old Douglas-fir. The Qiagen Midi RNeasy kit (Qiagen Inc., Mississauga, Canada) was used to clean up the extracted RNA and the SMART cDNA library kit (BD Biosciences Clontech, Palo Alto, CA) was used to synthesize cDNA. An aliquot of the synthesized second-strand cDNA was used in the polymerase chain reaction (PCR) cloning of PmTLP cDNA.

PCR cloning of PmTLP cDNA. Using N-terminal and internal amino acid sequence results, a degenerate $5^{\prime}$ forward primer, THA-1 (5'-GCIACITTTACIATAGTIAATCA-3', corresponding to $\mathrm{N}$-terminal amino acid sequence ATFTIVNQ), and a degenerate $3^{\prime}$ reverse primer, THA-3 (5'-ATAIGCCTGIGGACACTGIGC-3', corresponding to internal amino acid sequence AQCPQAY), were synthesized and used in PCR with double-stranded cDNA as template. "I" was used to designate deoxyinosine in the primer design. This yielded a 540-bp PCR fragment whose nucleotide sequence was used to design a gene-specific reverse primer from 383 to 406 bp, THA-5 (5'-ACTTGCAATTGCGTTGGGCAATTC-3'). This primer was used with Clontech's PCR 5' primer (BD Biosciences, Mississauga, Canada) for 5'-rapid amplification of cDNA end (RACE) to clone the $5^{\prime}$ end of the gene. To obtain the full-length sequence of PmTLP, a forward primer (FTH 5': 5'-GTGTTGTAGTACTGCTTATTCATTG- $3^{\prime}$ ) was designed from the $5^{\prime}$ untranslated region (UTR) and paired with oligo d(T)30 to perform 3'-RACE. All primers were synthesized by Invitrogen Life Technologies (Burlington, ON, Canada). PCR amplification was carried out using Taq PCR Master Mix Kit (Qiagen Inc.) on a GeneAmp PCR System 2400 Thermocycler (Perkin-Elmer Canada Ltd., Montreal) with the following reaction conditions: an initial denaturation step at $94^{\circ} \mathrm{C}(3 \mathrm{~min})$ followed by 35 cycles of denaturation at $94^{\circ} \mathrm{C}(30 \mathrm{~s})$, with the following primer-specific annealing temperatures and times: $40^{\circ} \mathrm{C}$ for Tha- 1 and Tha- 3 ( $1 \mathrm{~min}), 65^{\circ} \mathrm{C}$ for Clontech's $5^{\prime}$ primer and Tha-5 (4 min) and $50^{\circ} \mathrm{C}$ for FTH $5^{\prime}$ primer and oligo d(T) $3^{\prime}$ primer (1 min), primer extension at $72^{\circ} \mathrm{C}(2 \mathrm{~min})$, and ending with a final extension at $72^{\circ} \mathrm{C}$ (10 min). PCR products were separated on $1 \%$ agarose gels in $1 \times$ Tris-boric acid-EDTA $(178 \mathrm{mM}$ Tris base, $178 \mathrm{mM}$ boric acid, and $1 \mathrm{mM}$ EDTA) and purified with Qiagen's QIAquick gel extraction kit. DNA fragments were cloned into pGEM-T easy vector system (Promega Corporation, Madison, WI).

Genomic DNA extraction and PCR. Genomic DNA (gDNA) was extracted from freeze-dried, P. weirii-infected Douglas-fir using Qiagen DNeasy Plant mini kit. PCR primers were designed based on PmTLP cDNA coding sequence as follows: the 5' end primer was a 29 mer with 22 bases derived from the start codon followed by PmTLP coding sequence (5'- caagcatATGGGGGAAAGAACAATAGCAG-3'), and the $3^{\prime}$ end primer was a $38 \mathrm{mer}$ with 23 bases derived from the stop codon and the $3^{\prime}$ end of PmTLP coding sequence in reverse complement (5'-cccgggatcctcgagTCAGGTGCAGAATGCGATGTTAT-3'). PCR amplification was carried out using the following reaction conditions: $94^{\circ} \mathrm{C}$ for $1 \mathrm{~min}$ followed by 35 cycles at $94^{\circ} \mathrm{C}$ for $1 \mathrm{~min}, 52^{\circ} \mathrm{C}$ for $45 \mathrm{~s}$, $72^{\circ} \mathrm{C}$ for $90 \mathrm{~s}$, and $10 \mathrm{~min}$ at $72^{\circ} \mathrm{C}$ to finish the reaction. The PCR fragment was cloned with the TOPO TA cloning kit (Invitrogen Life Technologies, Carlsbad, CA).

DNA sequencing and analysis. The derived plasmids were purified with Qiagen's QIAprep Spin Miniprep Kit and sequenced with a LI-COR 4200 Global Edition IR $^{2}$ DNA sequencer at the Centre for Environmental Health, Department of Biology, University of Victoria, B.C., Canada. A BLAST search (2) was performed to determine sequence homology at the website of the National Center for Biotechnology Information (United States). The Clustal W program (11), available at the European Bioinformatics Institute website, was used to perform multiple sequence alignment comparisons. LASERGENE software for Windows (DNASTAR Inc., Madison, WI) was used to calculate Mr, pI, and other biochemical features of PmTLP, including comparisons between the gDNA and cDNA coding sequences for the presence of introns. Prediction of signal peptide cleavage site location was performed using the SignalP V1.1 server at the website of the Center for Biological Sequence Analysis at the University of Denmark (21). The deduced amino acid sequence was assessed for potential glycosylation and phosphorylation sites using the NetNGlyc and NetPhos 2.0 (4) programs, respectively, at the Expert Protein Analysis System (ExPASy) proteomics server of the Swiss Institute of Bioinformatics.

Statistical analysis. PmTLP quantification data for $P$. weirii-infected roots were analyzed using one-way analysis of variance (ANOVA) for independent samples followed by Tukey's multiple range comparison test to determine the absolute difference between two sample means required for significance at $P<0.05$. A two-way ANOVA for independent samples was used to assess significance in mean PmTLP content in A. ostoyae-infected Douglas-fir roots due to season and pathogen infection $(P<0.05)$. ANOVAs were performed using the VassarStats website for statistical computation.

\section{RESULTS}

PmTLP identification and sequence analysis. While attempting to sequence a $27-\mathrm{kDa}$ endochitinase (ECP), previously shown to be induced in $P$. weirii-infected Douglas-fir roots (26) and heavily expressed in apoplastic fluid of needles from infected trees (Fig. 1A), we obtained internal peptide sequences for three fragments showing homology with a Pseudotsuga menziesii PR-5 TLP at amino acid positions 38-74, 149-165, and 203-213 as reported by Iglesias et al. (13). Using a lower protein concentration,
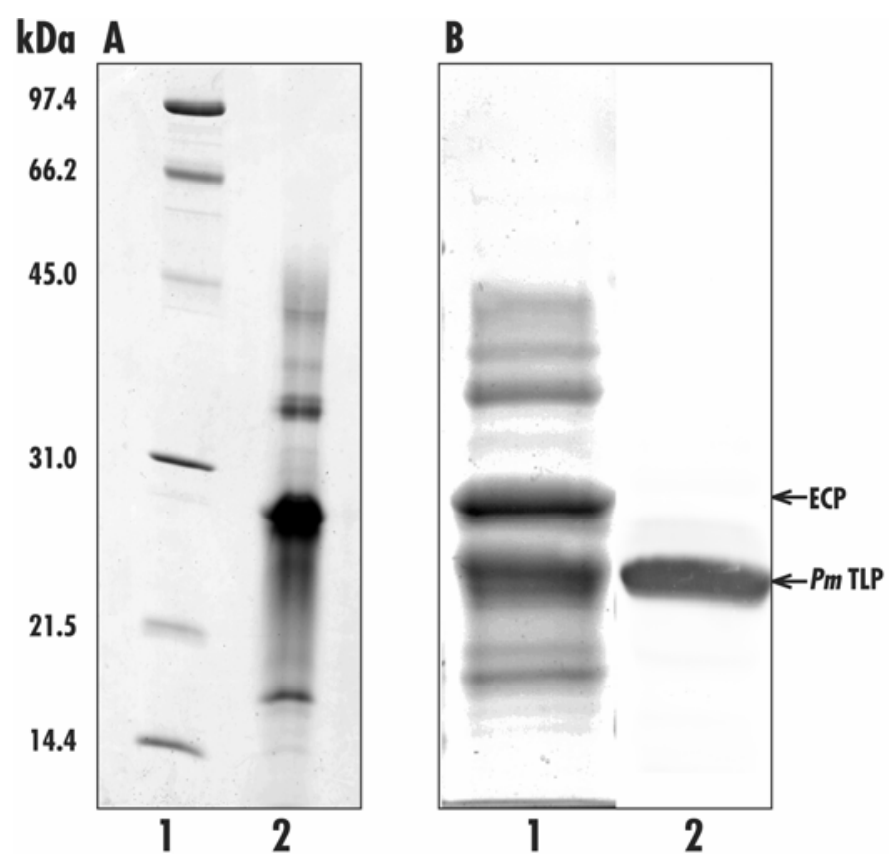

Fig. 1. A, One-dimensional gel electrophoresis of apoplastic proteins extracted from needles of a Phellinus weirii-infected Douglas-fir, stained with Coomassie blue. Lane 1 represents Bio-Rad molecular mass markers; and lane 2 is the apoplastic protein extract $(30 \mu \mathrm{g})$ showing heavy protein accumulation in the 24 to $27 \mathrm{kDa}$ size range. This protein region was directly excised from the Coomassie blue-stained gel and sent for internal amino acid sequence analysis. B, Lane 1 shows at least seven polypeptides detected in the apoplastic fluid (10 $\mu \mathrm{g}$ of protein load), with clear separation between two proteins at 24 (Pseudotsuga menziesii thaumatin-like proteins [PmTLP]) and 27 (endochitinase $[\mathrm{ECP}]) \mathrm{kDa}$; and lane 2 is a western immunoblot showing recognition of the 24-kDa polypeptide by PmTLP-pab. 
better peptide separation was achieved and two distinct proteins were clearly visible at 27 and $24 \mathrm{kDa}$ (Fig. 1B). The N-terminal amino acid sequence of the $27-\mathrm{kDa}$ polypeptide matched the sequence reported for ECP (26). The following sequence of $28 \mathrm{~N}$ terminal amino acids was identified for the $24-\mathrm{kDa}$ polypeptide termed PmTLP: ATFTIVNQXSQTVWGAGIPVGGGKQLGQ. Considerable overlap was observed between the N-terminal and the previously reported internal amino acid sequence NQCSYTVWAAGSPGGGKQLGQGETWSFDVAADTTGGR at amino acid position 38-58 (13). Because the internal amino acid sequence was derived by mass spectrum analysis and is based on finding the closest peptide matches to the query sequence, it is not

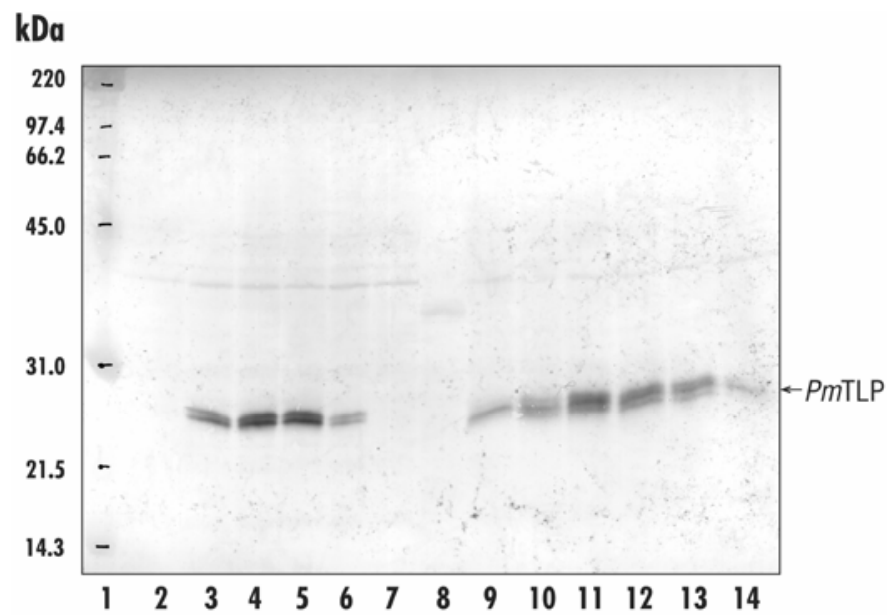

Fig. 2. Western immunoblot of Phellinus weirii-infected mature Douglasfir root bark tissue sampled within, adjacent, and distant to margins of ectotrophic mycelium on two different roots. One-dimensional gel electrophoresis was carried out using $50 \mu \mathrm{g}$ of total protein in each lane, and proteins were immobilized on immobilon-P membrane. Membranes were probed with Pseudotsuga menziesii thaumatin-like protein polyclonal antibody (PmTLP-pab) (1:500 dilution) overnight. Lane 1 is the rainbow molecular mass marker, and lanes 2 to 7 represent extracts from one tree: Prox-UNINF (lane 2), Prox-ADJ (lane 3), Prox-INF (lane 4), Dist-INF (lane 5), Dist-ADJ (lane 6), and Dist-UNINF (lane 7). Lane 8 is $P$. weirii mycelial extract. Lanes 9 to 14 represent extracts from a second root: ProxUNINF (lane 9), Prox-ADJ (lane 10), Prox-INF (lane 11), Dist-INF (lane 12), Dist-ADJ (lane 13), and Dist-UNINF (lane 14). The arrow indicates the position of PmTLP.

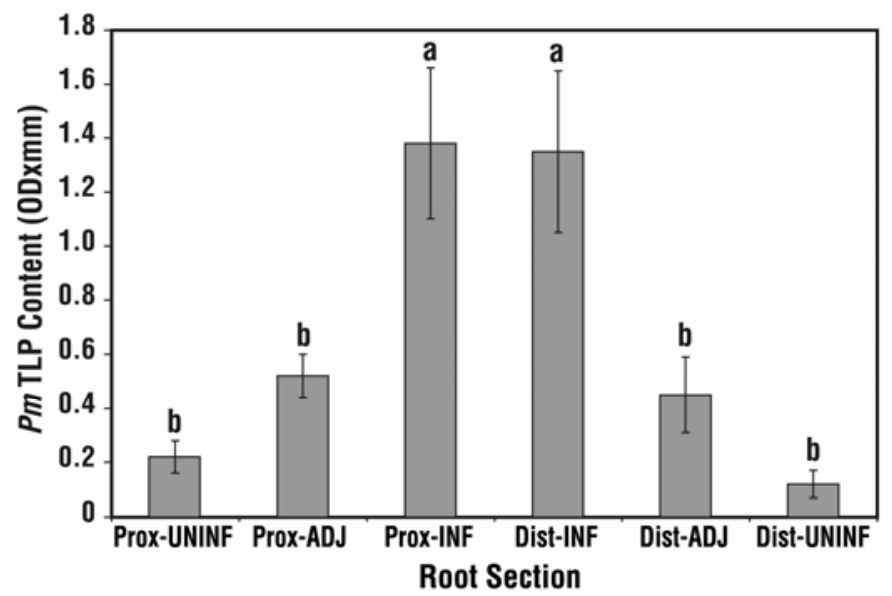

Fig. 3. Mean Pseudotsuga menziesii thaumatin-like proteins (PmTLP) accumulation in Phellinus weirii-infected 24-year-old mature Douglas-fir roots sectioned in the uninfected (UNINF), adjacent-to-infected (ADJ), and infected (INF) areas of the root, both proximal (Prox) and distal (DIST) from the inoculation point. Results are the mean of 12 roots, and bars represent standard errors of the means. Different letters indicate significant differences in PmTLP expression between root sections $(P<0.05)$ according to Tukey's analysis. a perfect match to the sequence obtained by $\mathrm{N}$-terminal analysis. To further characterize PmTLP, a peptide was synthesized against a 29-amino-acid-long sequence (NQCSYTVWAAGSPGGGKQLGQGETWSFDVAADTTGGR) showing a high antigenic index for antibody production. The PmTLP-pab specifically detected the 24-kDa polypeptide (Fig. 1B).

Quantification of PmTLP in Douglas-fir roots. Western immunoblot analysis using PmTLP-pab was carried out to determine antibody specificity and to quantify PmTLP concentration in various regions of infected roots. In most tissues analyzed, the antibody detected two polypeptides in close proximity in the 24-kDa size range in Douglas-fir roots (Fig. 2). Mycelial extracts of $P$. weirii were included in the western blot analysis; however, the antibody only recognized conifer proteins and did not crossreact with any fungal antigens. Six root sections from each of 12 $P$. weirii-infected Douglas-fir roots were processed by SDS-PAGE and western immunoblot using PmTLP-pab as a probe. In $P$. weirii-infected root regions, mean PmTLP was sixfold higher than that in uninfected tissues $(P<0.01)$ both proximally and distally from the inoculation point (Fig. 3). PmTLP accumulation in infected regions was higher and significantly different from areas adjacent to infected regions in both proximal and distal ends of the root $(P<0.05)$. However, the level of PmTLP was not significantly different between areas adjacent to infected regions and uninfected regions $(P>0.05)$, both proximally and distally from the point of inoculation (Fig. 3).

In Armillaria-infected Douglas-fir roots, the level of PmTLP was significantly higher around the region of infection than in uninfected regions $(P<0.05)$ during all three sampling months (Fig. 4). In May, area around the region of infected root bark showed significantly lower levels of PmTLP accumulation than in July and September $(P<0.05)$. No significant difference was observed between the uninfected regions in different months $(P>0.05)$.

Presence of $\boldsymbol{P m}$ TLP isoforms. Two-dimensional electrophoresis of the distal infection region of a Douglas-fir root followed by silver staining revealed over 500 well-resolved protein spots (Fig. 5A). Western immunoblot analysis of the same sample using PmTLP-pab, detected two polypeptides (Fig. 5B). By comparing the spot pattern of the silver-stained 2-D gel and the 2-D western immunoblot, we matched the proteins and determined that the two polypeptides detected by PmTLP-pab are between 24 to $25 \mathrm{kDa}$ with an approximate $\mathrm{pI}$ of 4.0 .

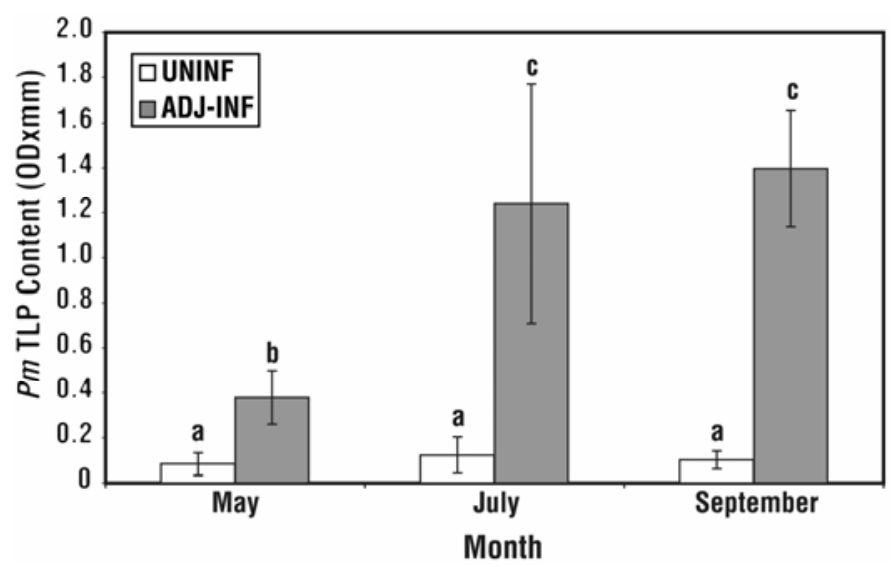

Fig. 4. Relative Pseudotsuga menziesii thaumatin-like proteins (PmTLP) accumulation in Armillaria ostoyae-infected 25-year-old Douglas-fir root bark sampled in the uninfected (UNINF) and adjacent-to-infected (ADJ-INF) regions $(50 \mu \mathrm{g}$ of protein load). Roots were sampled during the months of May, July, and September. Reported results are the mean of five different roots, and the bars represent standard error of the means. Different letters indicate significant differences $(P<0.05)$ in PmTLP expression between treatments according to Tukey's analysis. 
Sequence analysis and characterization of PmTLP cDNA. To confirm identity and obtain the full-length sequence for PmTLP, the gene encoding this protein was cloned using a PCRbased procedure. Figure 6 describes the 1,017-bp PmTLP cDNA (GenBank Accession No. AY315151) structure. Comparison of the N-terminal protein sequence with that deduced from the cDNA sequence indicated that the $\mathrm{N}$-terminal of the mature protein begins at position 30 of the open reading frame. This corresponds with the presence of a signal peptide cleavage site predicted to occur after a glycine residue between positions 29 to 30 in the amino acid sequence. Cleavage of this 29-amino-acid-long leader sequence results in a 204-amino-acid-long mature PmTLP with a calculated size of $21.1 \mathrm{kDa}$ and an isoelectric point of 3.7. The deduced PmTLP amino acid sequence showed no vacuolar targeting signal sequence suggesting its intercellular localization. There were minor discrepancies between the N-terminal sequence derived from the 1-D microsequencing analysis and that deduced from the cDNA denoted by boxes in Figure 6. Posttranslational modification assessment for PmTLP deduced amino acid sequence revealed predicted $\mathrm{N}$-glycosylation and phosphorylation sites. Asparagine residues predicted to be $\mathrm{N}$-glycosylated (in the sequence series Asn-X-Ser/Thr) occurred at positions 117 $\left(\mathrm{N}^{117} \mathrm{GSN}\right)$ and $154\left(\mathrm{~N}^{154} \mathrm{VTA}\right)$. Five probable phosphorylation sites were predicted to occur on $\mathrm{Ser}^{128}, \mathrm{Ser}^{144}, \mathrm{Ser}^{195}, \mathrm{Tyr}^{181}$, and $\mathrm{Tyr}^{187}$.

PmTLP introns. Comparison of three PmTLP genomic PCR sequences with the cDNA revealed different sized introns close to the N-terminal. Two of the gDNA sequences (GenBank Accession No. AY315152) revealed a 112-bp intron localized between nucleotide position 144 and 145 of the cDNA sequence (Fig. 6). In the third gDNA sequence (GenBank Accession No. AY661266), the intron was at the same position but 128 bp long. With the exception of three amino acids, the deduced amino acid sequence of all three gDNAs was identical to that of the cDNA deduced sequence. This finding further supports the presence of at least two PmTLP isoforms, each with one intron of variable size.

Sequence alignment comparisons. The deduced PmTLP amino acid sequence shared significant homology with other conifer and dicotyledonous plant TLPs (Fig. 7). Within conifers, PmTLP shared $63 \%$ identity with another PmTLP, 62\% identity with a Japanese cedar form (Cryptomeria japonica), and 58\% identity with a thaumatin-like pollen allergen protein from mountain cedar (Juniperus ashei). PmTLP also shared extensive homology with TLPs and related antifungal PR-5 proteins like osmotins and zeamatins from dicotyledonous plants such as grape (Vitis riparia) and maize (Zea mays). Of interest are the 16 cysteine residues involved in the assemblage of eight disulfide linkages, which are conserved in all six sequences compared in Figure 7. Five acidic residues $\left(\mathrm{Arg}^{73}, \mathrm{Glu}^{113}, \mathrm{Asp}^{126}, \mathrm{Asp}^{131}\right.$, and $\mathrm{Asp}^{213}$ ) believed to be involved in formation of an acidic cleft in the 3-D structure of zeamatin were also identified in the deduced amino acid sequence of PmTLP.

\section{DISCUSSION}

A $24-\mathrm{kDa}$ protein was found to be secreted into and easily extractable from the apoplastic fluid of needles of $P$. weirii-infected Douglas-fir. Mass spectrometry analysis yielded three consensus regions showing similarity to a PR-5 TLP identified in Douglasfir seed (13). N-terminal amino acid sequence analysis supported homology with members of thaumatin-like PR-5 proteins. Because of the significance of TLPs in plant defense and their potential inhibitory activity on fungal pathogens, an antibody was developed to monitor PmTLP expression in Douglas-fir tissues. The most conserved internal amino acid region showing the highest antigenic index was selected for antibody production. PmTLP-pab was highly specific for its antigen and did not cross-react with any $P$. weirii proteins, indicating a protein of host origin. It detected two polypeptides in close proximity, between 24 to $25 \mathrm{kDa}$, suggesting expression of more than one PmTLP isoform. This observation was further supported by 2-D western immunoblot analysis, where two polypeptides were detected by the PmTLPpab in the 24 to $25 \mathrm{kDa}$ range.

A detailed analysis of PmTLP expression along the path of $P$. weirii-ectotrophic mycelial growth was undertaken for infected Douglas-fir roots excavated and sampled concurrently to elimi-

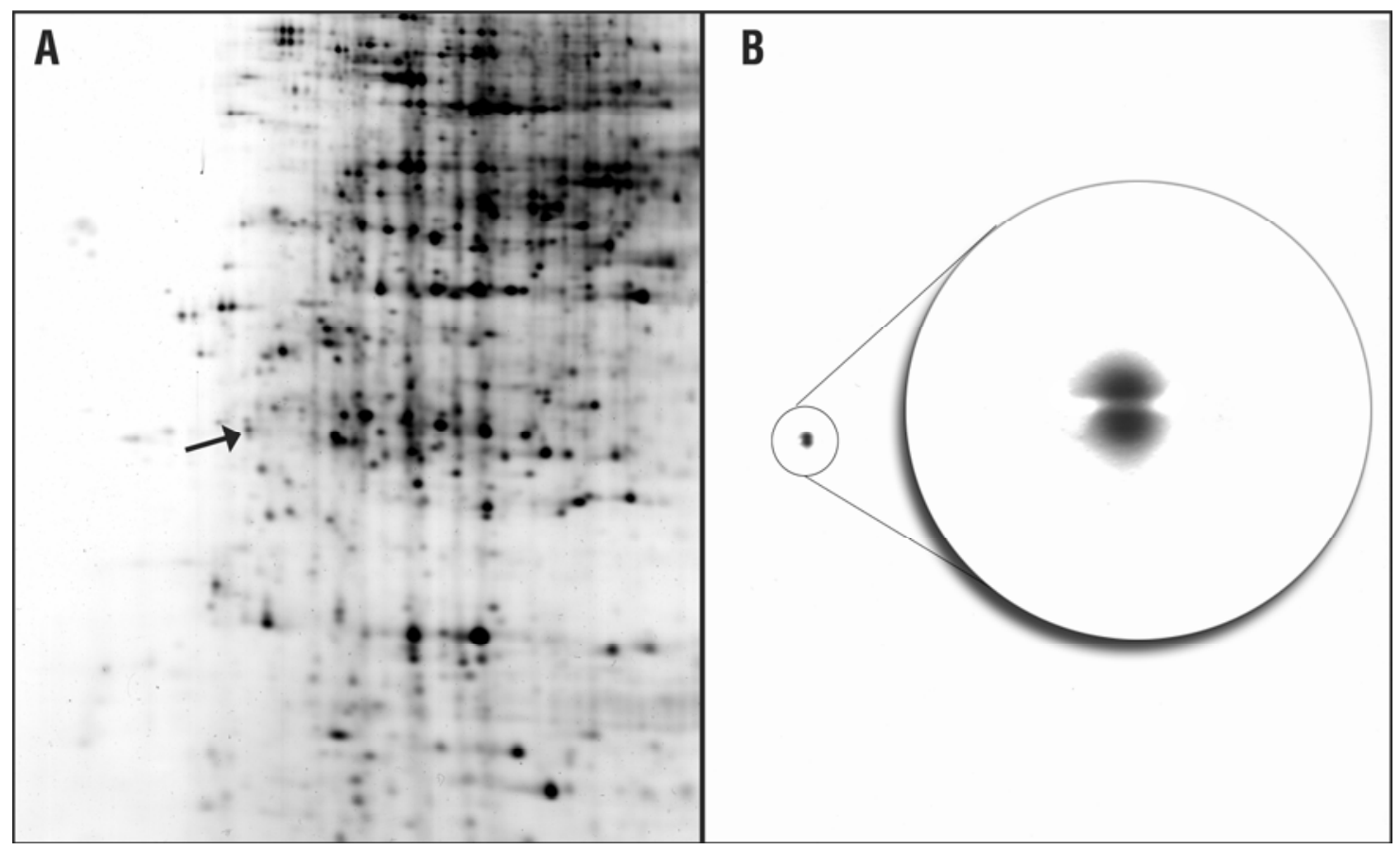

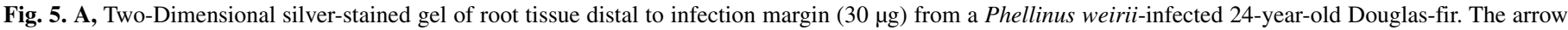

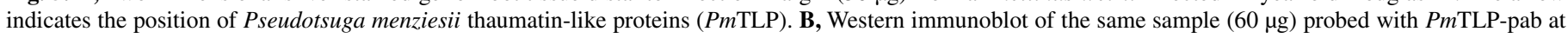
1:500 dilution, with a close-up view of the two PmTLP isoforms. 
nate any seasonal effects. By sampling six different regions of the same root, we were able to show that PmTLP synthesis was induced by fungal infection. There was a sixfold greater PmTLP concentration in tissues close to the inoculation point than in tissues outside the region of ETM. Tissues sampled distally and proximally had similar PmTLP concentrations.

PmTLP expression also fluctuated between A. ostoyae-infected and -uninfected Douglas-fir roots. This was true in the September sampling when PmTLP induction in tissues directly adjacent to infection was more than 10 -fold higher than in uninfected tissues.
Because mycelial fans of $A$. ostoyae come in direct contact with the living cambium tissue, PmTLP concentrations sharply increased in tissues adjacent to infection versus uninfected tissues. We were able to monitor seasonal differences in the A. ostoyaeinfected roots and show PmTLP elevation in July and September. While analyzing expression of another PR protein (ECP) in Douglas-fir roots, Robinson et al. (26) found higher ECP accumulation in A. ostoyae- than in $P$. weirii-infected roots; however, ECP expression showed little fluctuation throughout the sampling period.

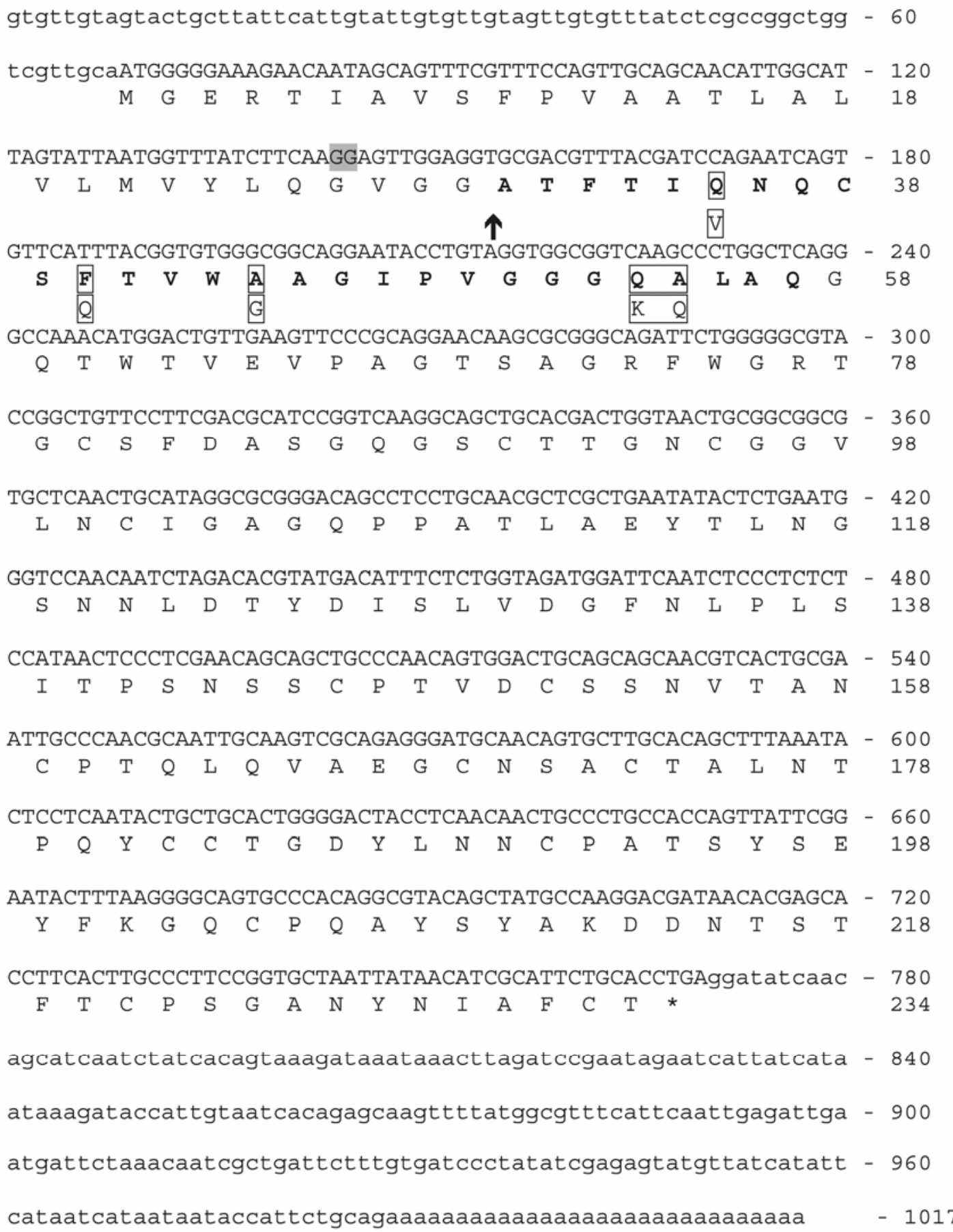

Fig. 6. Complete nucleotide sequence for the gene encoding a PR-5 Douglas-fir thaumatin-like protein (PmTLP) and its deduced amino acid sequence. The amino acid sequence is shown using the single letter code under the nucleotide sequence. The numbers on the right side indicate either nucleotide or amino acid positions. The open reading frame is capitalized and the $5^{\prime}$ and $3^{\prime}$ untranslated region (UTR) are in lower case. An asterisk indicates the stop codon. The PmTLP sequence has a 68-bp 5' UTR, a 702-bp open reading frame encoding the PmTLP protein, and a 247-bp 3' UTR including the 30-bp poly (A) tail. Amino acids in bold represent the $\mathrm{N}$-terminal region, with those in boxes showing minor discrepancy between the deduced amino acid sequence and $\mathrm{N}$-terminal microsequence. An upward arrow indicates the predicted location of a signal peptide cleavage site between amino acids 29 and 30 at $155 \mathrm{bp}$. A 112 -bp intron was found in the genomic DNA between two guanidine residues at 144 and 145 bp highlighted in the cDNA sequence. 
Similar to other PR proteins, TLP synthesis can occur under general stress conditions and may be constitutively present in response to environmental or physiological stimuli. Regalado and Ricardo (24) reported the constitutive presence of chitinase and TLPs in the intercellular fluid of healthy, unstressed leaves of $L u$ pinus albus plants and suggest that perhaps they are part of a preformed defense response. We also detected the systemic distribution of PmTLP in Douglas-fir needle apoplastic fluid (unpublished data), demonstrating that this protein is not exclusively root-specific. However, its significant quantitative induction in Douglas-fir roots infected by two different phytopathogenic fungi is a good indicator of a possible defense-related compound.

The full-length PmTLP gene encodes a precursor protein with a 29-amino-acid-long, relatively hydrophobic, signal peptide but lacks a C-terminal vacuolar targeting signal, indicating that PmTLP is secreted out of the cytoplasm and into the apoplast. The mature protein lacks this sequence, as evidenced by the location of the predicted signal peptide cleavage site just before the start of the N-terminal. The PCR-based gene cloning procedure resulted in a 1,017-bp full-length cDNA sequence. The discrepancy observed between the deduced amino acid sequence derived from the cDNA and the $\mathrm{N}$-terminal sequence is minimal and may be attributable to different sample sources being used as templates for analysis. Additionally, the most common of several isoforms may have been picked up by the DNA primers and cloned. Polymorphisms are typical of large gene families like the PR proteins. Having obtained three PmTLP gDNA clones with different sized introns suggests allelic polymorphism of the PmTLP gene and helps explain the double banding and spotting pattern observed on 1-D and 2-D immunoblots.

Given the considerable consensus pattern that our PmTLP shared with other TLPs, we confirmed the identity of the clone as a TLP. Based on the deduced amino acid sequence, the predicted PmTLP size of $21 \mathrm{kDa}$ differed slightly from the observed 24-kDa polypeptide detected on SDS gels and western immunoblots. This 3-kDa size discrepancy may be a result of posttranslational modification, as suggested by the two predicted glycosylation sites and five predicted phosphorylation sites identified in the amino acid sequence. The acidic nature of PmTLP observed

\section{PmTLP \\ D.Fir seed TLP \\ W. Cedar TLP \\ J.Cedar TLP \\ Grape Thaumatin \\ Maize Zeamatin \\ PmTLP \\ D.Fir seed TLP \\ W. Cedar TLP \\ J.Cedar TLP \\ Grape thaumatin \\ Maize zeamatin}

\section{PmTLP \\ D.Fir seed TLP \\ W. Cedar TLP \\ J.Cedar TLP \\ Grape Thaumatin \\ Maize Zeamatin}

PmTLP
D.Fir seed TLP
W.Cedar TLP
J.Cedar TLP
Grape Thaumatin
Maize Zeamatin
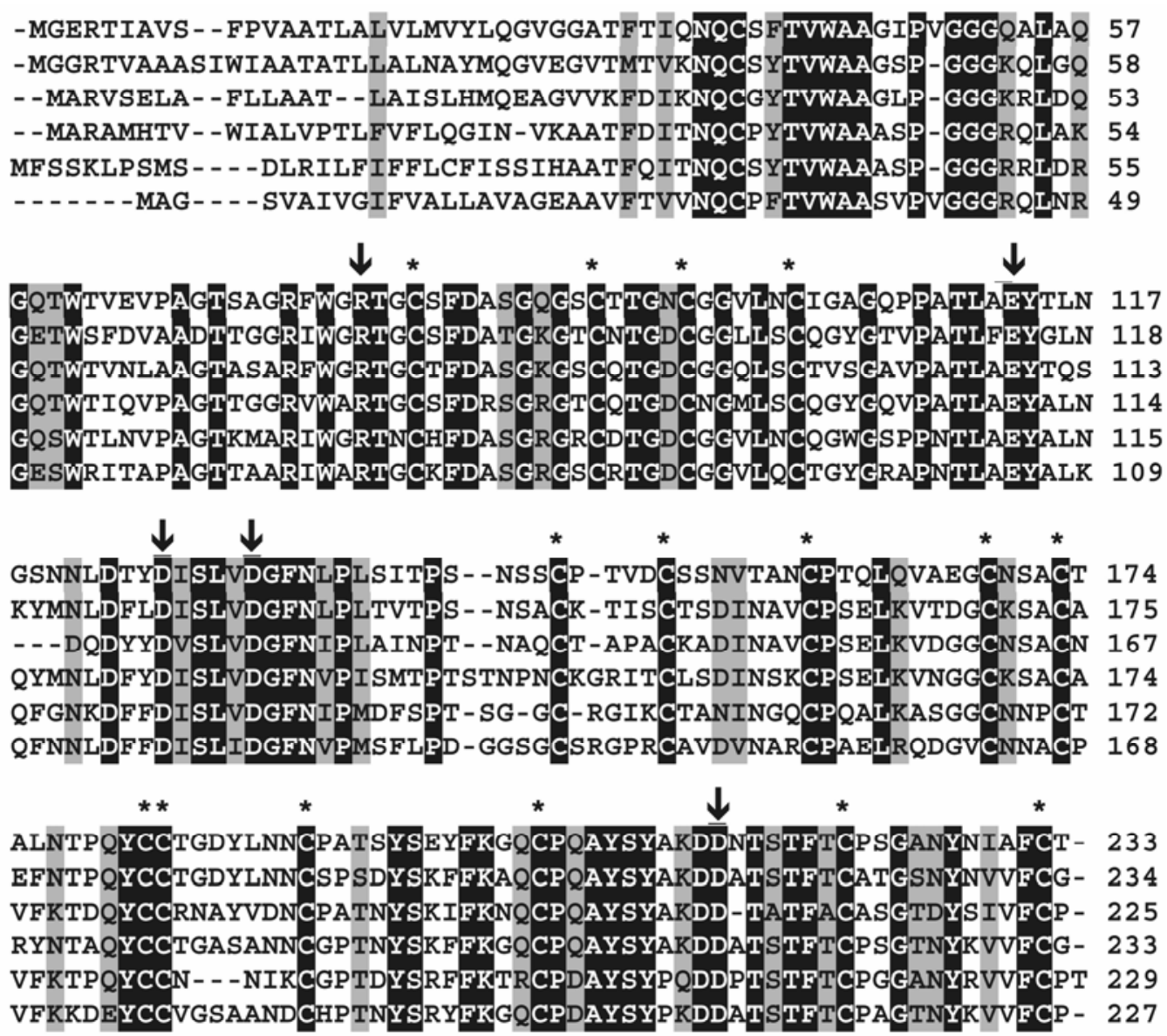

\section{PmTLP \\ D.Fir seed TLP \\ W. Cedar TLP \\ J.Cedar TLP \\ Grape Thaumatin \\ Maize Zeamatin}

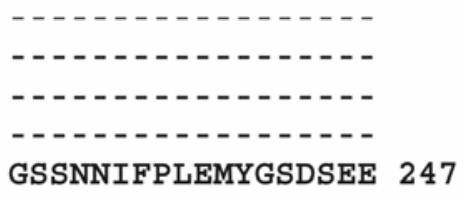

GSSNNIFPLEMYGSDSEE 247

Fig. 7. Amino acid sequence alignment of Pseudotsuga menziesii thaumatin-like proteins (PmTLP) and related PR-5 proteins. Amino acids shaded in black indicate identical residues in all sequences in the alignment, while those shaded in gray indicate well-conserved substitutions. The sequences listed represent PmTLP (GenBank Accession No. AY315151), Douglas-fir (Pseudotsuga menziesii) seed TLP (GenBank Accession No. AJ131731), Ozark white cedar (Juniperus ashei) PR-5 pollen allergen (AF121776), Japanese cedar (Cryptomeria japonica) TLP (AB081304), grape (Vitis riparia) thaumatin (AF178653), and an antifungal zeamatin-like protein from maize (Zea mays; P33679). Asterisks indicate the 16 conserved cysteine residues. Arrows indicate position of acidic side-chains contained in the acidic cleft region of maize zeamatin. 
on 2-D immunoblots and confirmed by the isoelectric point calculation is consistent with other apoplastic PR proteins (28). Secreted PR proteins are believed to have a role in resistance, either directly through antimicrobial activity or indirectly through signal transduction (5).

The PmTLP cDNA sequence shared significant homology with other antifungal TLPs isolated from a diverse group of plants. Included in this group are TLPs shown to have antifungal activity in maize as well as pollen allergens from two cedar varieties $(3,10,17)$. The conservation in the 16 cysteine residues responsible for disulfide bridges was evident. These linkages not only help stabilize the molecule and allow for correct folding but also make TLPs resistant to protease degradation and may be essential for antifungal activity $(15,25)$. The 3 -D crystal structure of PR-5 proteins such as zeamatin from maize and osmotin from tobacco have been used as model templates to determine the occurrence of a negatively charged surface cleft structure on related proteins $(3,14)$. This acidic cleft is comprised of five amino acids (arginine, glutamic acid, and three aspartic acid residues) and is believed to be involved in a PR-5-fungal cell interaction that permeabilizes the fungal cell membrane, disrupting the osmotic balance inside hyphal cells leading to cell rupture (3). This consensus pattern was found in the deduced PmTLP sequence and matched the same residues in zeamatin known to be involved in acidic cleft formation. Although the surface characteristics of PmTLP can only be confirmed by X-ray crystallography or protein modeling, the consensus amino acid sequence may support this structural motif. The cedar allergens also expressed the same conserved region, which is consistent with recent findings showing that a previously characterized apple allergen also contained the acidic cleft and demonstrated fungal growth inhibition (15).

The PmTLP characterized in this study is one of few such conifer PR proteins to be isolated and analyzed using genomic and proteomic approaches and represents just one component of a much larger network of defense responsive genes and resistance elements needed to successfully inhibit $P$. weirii infection in Douglas-fir roots. Work continues in order to express and purify the recombinant PmTLP for use in antifungal assays.

\section{ACKNOWLEDGMENTS}

Financial support was provided by Forest Renewal British Columbia and Forest Innovation and Investment (to R. N. Sturrock and A. K. M. Ekramoddoullah). We thank J. Davidson and R. Robinson for root tissue collection; M. K. Young of the Beckman Research Institute of the City of Hope, Duarte, CA, for the mass spectrometry analysis; S. Kielland at the University of Victoria microsequencing lab for N-terminal analysis; and D. Macey and H. Williams for critical review of this manuscript.

\section{LITERATURE CITED}

1. Abad, L. R., D’Urzo, M. P., Liu, D., Narasimhan, M. L., Reuveni, M., Zhu, J. K., Niu, X., Singh, N. K., Hasegawa, P. M., and Bressen, R. A. 1996. Antifungal activity of tobacco osmotin has specificity and involves plasma membrane permeabilization. Plant Sci. 118: 11-23.

2. Altschul, S. F., Madden, T. L., Schaffer, A. A., Zhang, J., Zhang, Z., Miller, W., and Lipman, D. J. 1997. Gapped BLAST and PSI-BLAST: A new generation of protein database search programs. Nucleic Acids Res. 25:3389-3402.

3. Batalia, M. A., Monzingo, A. F., Ernst, S., Roberts, W., and Robertus, J. D. 1996. The crystal structure of the antifungal protein zeamatin, a member of the thaumatin-like, PR-5 protein family. Nat. Struct. Biol. 3:19-23.

4. Blom, N., Gammeltoft, S., and Brunak, S. 1999. Sequence and structurebased prediction of eukaryotic protein phosphorylation sites. J. Mol. Biol. 294:1351-1362.

5. Christensen, A. B., Cho, B. H., Naesby, M., Gregersen, P. L., Brandt, J., Madri-Ordenãna, K., Collinge, D. B., and Thordal-Christensen, H. 2002. The molecular characterization of two barley proteins establishes the novel PR-17 family of pathogenesis-related proteins. Mol. Plant Pathol. 3:135-144.
6. Eden, L., Hesling, L., Klock, R., Ledeboer, A. M., Meat, J., Toonen, M. Y., Visser, C., and Verrips, C. Y. 1982. Cloning of cDNA encoding the sweet tasting plant protein thaumatin and its expression in Escherichia coli. Gene 18:1-12.

7. Ekramoddoullah, A. K. M., and Davidson, J. J. 1995. A method for the determination of conifer foliage protein extracted using sodium dodecyl sulfate and mercaptoethanol. Phytochem. Anal. 6:20-24.

8. Ekramoddoullah, A. K. M., and Tan, Y. 1998. A modification for the improved analysis of differential protein accumulation by twodimensional polyacrylamide gel electrophoresis. Phytochem. Anal. 9:159-161.

9. Ekramoddoullah, A. K. M., Taylor, D., and Hawkins, B. J. 1995. Characterization of a fall protein of sugar pine and detection of its homologue associated with frost hardiness of western white pine needles. Can. J. For. Res. 25:1137-1147.

10. Futamura, N., Mukai, Y., Sakaguchi, M., Yasueda, H., Inouye, S., MidoroHoriuti, T., Goldblum, R. M., and Shinohara, K. 2002. Isolation and characterization of cDNAs that encode homologs of a pathogenesisrelated protein allergen from Cryptomeria japonica. Biosci. Biotechnol. Biochem. 66:2495-2500.

11. Higgins, D., Thompson, J., Gibson, T., Thompson, J. D., Higgins, D. G., and Gibson, T. J. 1994. Clustal W: Improving the sensitivity of progressive multiple sequence alignment through sequence weighting, position-specific gap penalties and weight matrix choice. Nucleic Acids Res. 22:4673-4680.

12. Hoffmann-Sommergruber, K. 2002. Pathogenesis-related (PR)-proteins identified as allergens. Biochem. Soc. Trans. 30:930-935.

13. Iglesias, R. G., Nicolas, G., and Babiano, M. J. 1999. Characterization of a cDNA encoding a thaumatin-like protein from Pseudotsuga menziesii. Plant Physiol. 119:1149.

14. Koiwa, H., Kato, H., Nakatsu, T., Oda, J., Yamada, Y., and Sato, F. 1999. Crystal structure of tobacco PR-5d protein at $1.8 \AA$ resolution reveals a conserved acidic cleft structure in antifungal thaumatin-like proteins. J. Mol. Biol. 286:1137-1145.

15. Krebitz, M., Wagner, B., Ferreira, F., Peterbauer, C., Campillo, N., Witty, M., Kolarich, D., Steinkellner, H., Scheiner, O., and Breiteneder, H. 2003. Plant-based heterologous expression of Mal D 2, a thaumatin-like protein and allergen of apple (Malus domestica), and its characterization as an antifungal protein. J. Mol. Biol. 329:721-730.

16. Linthorst, H. J. M. 1991. Pathogenesis-related proteins of plants. CRC Cri. Rev. Plant Sci. 10:123-150.

17. Midoro-Horiuti, T., Goldblum, R. M., Kurosky, A., Wood, T. G., and Brooks, E. G. 2000. Variable expression of pathogenesis-related protein allergen in mountain cedar (Juniperus ashei) pollen. J. Immunol. 164:2188-2192.

18. Morrison, D. J., Merler, H., and Norris, D. 1991. Detection, recognition and management of Armillaria and Phellinus root diseases in the southern interior of British Columbia. Forestry Canada and B.C. Ministry of Forests. Canada-British Columbia Partnership Agreement on Forest Resource Development: FRDA II. FRDA Rep. 179.

19. Morrison, D. J., Williams, R. E., and Whitney, R. D. 1991. Infection, disease development, diagnosis, and detection. Pages 62-75 in: Armillaria Root Disease. C. G. Shaw, III and G. A. Kile, eds. U.S. Dep. Agric. For. Serv. Agric. Handb. No. 691.

20. Mullick, D. B., and Jensen, G. D. 1973. New concepts and terminology of coniferous periderms: Necrophylactic and exophylactic periderms. Can. J. Bot. 51:1459-1470.

21. Nielsen, H., Engelbrecht, J., Brunak, S., and von Heijne, G. 1997. Identification of prokaryotic and eukaryotic signal peptides and prediction of their cleavage sites. Protein Eng. 10:1-6.

22. Rabilloud, T. 1992. A comparison between low background silver diamine and silver nitrate protein stains. Electrophoresis 13:429-439.

23. Ramamoorthy, V., Raguchander, T., and Samiyappan, R. 2002. Induction of defense-related proteins in tomato roots treated with Pseudomonas fluorescens Pf1 and Fusarium oxysporum f. sp. lycopersici. Plant Soil 239:55-68.

24. Regalado, A. P., and Ricardo, C. P. P. 1996. Study of intercellular fluid in healthy Lupinus albus organs. Plant Physiol. 110:227-232.

25. Roberts, W. K., and Selitrennikoff, C. P. 1990. Zeamatin, an antifungal protein from maize with membrane-permeabilizing activity. J. Gen. Microbiol. 136:1771-1778.

26. Robinson, R. M., Sturrock, R. N., Davidson, J. J., Ekramoddoullah, A. K. M., and Morrison, D. J. 2000. Detection of a chitinase-like protein in the roots of Douglas-fir trees infected with Armillaria ostoyae and Phellinus weirii. Tree Physiol. 20:493-502.

27. Schultz, D. J., Craig, R., Cox-Foster, D. L., Mumma, R. O., and Medford, J. I. 1994. RNA isolation from recalcitrant plant tissue. Plant Mol. Biol. Rep. 12:310-316.

28. Selitrennikoff, C. P. 2001. Antifungal proteins. Appl. Environ. Microbiol. 67:2883-2894 
29. Sturrock, R. N., and Reynolds, G. 1998. A new technique for inoculation of conifer seedling roots with the laminated root rot pathogen, Phellinus weirii. Can. J. Plant Pathol. 20:324-330.

30. Thies, W. G., and Sturrock, R. N. 1995. Laminated root rot in western North America. U.S. Dep. Agric. For. Serv. PNW-GTR-349.

31. Van Loon, L. C. 1985. Pathogenesis-related proteins. Plant Mol. Biol. 4:111-116.

32. Van Loon, L. C., and Van Strien, E. A. 1999. The families of pathogenesis-related proteins, their activities, and comparative analysis of PR-1 type proteins. Physiol. Mol. Plant Pathol. 55:85-97.

33. Wallis, G. W., and Reynolds, G. 1965. The initiation and spread of Poria weirii root rot of Douglas-fir. Can. J. Bot. 43:1-9.

34. Yu, X. M., and Griffith, M. 1999. Antifreeze proteins in winter rye leaves form oligomeric complexes. Plant Physiol. 119:1361-1369.

35. Zamani, A., Sturrock, R. N., Ekramoddoullah, A. K. M., Wiseman, S. B., and Griffith, M. 2003. Endochitinase activity in the apoplastic fluid of Phellinus weirii-infected Douglas-fir and its association with over wintering and antifreeze activity. Forest Pathol. 33:299-316. 